\author{
HANNA FABCZAK, LESZEK KUŹNICKI
}

Instytut Biologii Doświadczalnej im. M. Nenckiego PAN

02-093 Warszawa ul Pasteura 3

e-mail:h.fabczak@nencki.edu.pl

\title{
PROFESOR ANDRZEJ GREBECKI (1934-2021) - BADACZ FIZJOLOGII RUCHU KOMÓREK, NAUCZYCIEL, WYCHOWAWCA
}

14 stycznia 2021 r. po długiej chorobie odszedł profesor Andrzej Grębecki wybitny biolog komórki, zasłużony dla nauki w Polsce i na świecie, nauczyciel i wychowawca. Profesor Andrzej Grębecki ukończył Wydział Matematyczno-Przyrodniczy Uniwersytetu

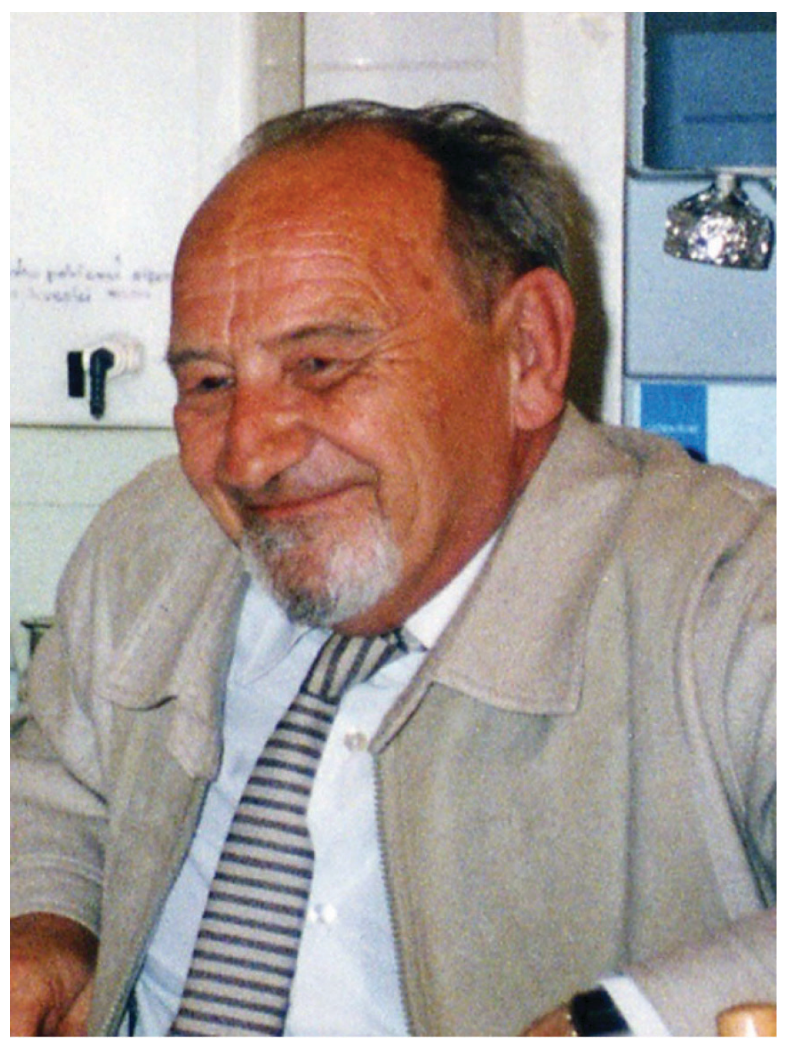

Profesor Andrzej Grębecki (1934-2021)
Łódzkiego w 1952 r., a w 1956 r. obronił pracę doktorska pod kierunkiem prof. Jana Dembowskiego. Profesor Grębecki przez wiele lat (1973-2002) kierowal Pracownia Morfodynamiki Prostych Systemów Ruchowych w Zakładzie Biologii Komórki, Instytutu Nenckiego PAN. Ponadto aktywnie uczestniczył w życiu Instytutu, w którym m.in. pełnił funkcję zastepcy dyrektora $\mathrm{d} / \mathrm{s}$ naukowych (1975-1981) oraz kierownika studium doktoranckiego (1975-1979). Przez dwie kadencje w latach 1984-1989 był przewodniczacym Rady Naukowej Instytutu Nenckiego. Profesor Grębecki w latach 1984-1989 był członkiem Rady Polskiej Sieci Biologii Komórkowej i Molekularnej UNESCO, a 19931997 członkiem International Commission of Protozoology.

Zainteresowania naukowe profesora Grębeckiego skupiały się na badaniu mechanizmów ruchu komórek. Był On autorem ponad 160 opublikowanych pozycji naukowych, obejmujacych pierwsze $\mathrm{w}$ literaturze prace o roli wapnia w regulacji ruchu rzęskowego. Następnie swoje zainteresowania naukowe profesor Grębecki skupił na badaniach fizjologii ruchu amebowego, których wyniki publikował w bardzo prestiżowych czasopismach międzynarodowych: m.in. Journal of Cell Science, European Journal of Cell Biology, Cell Biology International Reports. Główne założenia dotyczące teorii ogólnego skurczu kortykalnego zawarł w obszernej monografii „Membrane and cytoskeleton flow in motile cells with emphasis on the contribution of free-living Amoebae", opublikowanej w International Review of Cytology

Zredagowano w oparciu o monografię prof. Leszka Kuźnickiego "Protozoologia w Polsce 1861-2001", wydaną przez Centrum Upowszechniania Nauki PAN w serii Problemy Naukowe Współczesności 2003. 
(1994). Dowodem międzynarodowego uznania dorobku profesora Grębeckiego było jego członkostwo w pracy komitetów redakcyjnych międzynarodowych czasopism naukowych: Acta Protozool. (Warszawa), Eur.J.Protistol. (Stuttgart) i Protistology (Omsk).

Za swoje osiagnięcia naukowe i organizacyjne był wielokrotnie nagradzany wyróżnieniami i odznaczeniami państwowymi (m.in. Krzyż Oficerski Orderu Odrodzenia Polski 1998).

\section{Profesor Andrzej Grębecki (1934-2021)}

Professor Andrzej Grębecki graduated from the Faculty of Mathematics and Natural Sciences of the University of Łódź in 1952, and in 1956 he defended his doctoral thesis under the supervision of prof. Jan Dembowski. For many years (1973-2002) Professor Grebecki headed the Laboratory of the Morphodynamics of Simple Movement Systems at the Department of Cell Biology, the Nencki Institute of the Polish Academy of Sciences. Moreover, he actively participated in the life of the Institute, he was the deputy director for research (1975-1981) and the head of the doctoral study (19751979). For two terms in 1984-1989 he was the chairman of the Scientific Council of the Nencki Institute. In 1984-1989 Professor Grębecki was a member of the Council of the UNESCO Polish Network of Cellular and Molecular Biology, and in 1993-1997 a member of the International Commission of Protozoology.

Professor Grebecki's research interests focused on studying the mechanisms of cell movement. He was the author of over 160 published scientific papers, including the first works in the literature on the role of calcium in the regulation of ciliary movement. Then, Professor Grebecki focused his scientific interests on research on the physiology of the amoeba movement, the results of which he published in very prestigious international journals: Journal of Cell Science, European Journal of Cell Biology, Cell Biology International Reports. The main assumptions regarding the theory of general cortical contraction were included in the extensive monograph "Membrane and cytoskeleton flow in motile cells with emphasis on the contribution of free-living Amoebae", published in the International Review of Cytology (1994). The proof of the international recognition of Professor Grebecki's achievements was his membership in the work of editorial committees of international scientific journals: Acta Protozool. (Warsaw), Eur.J.Protistol. (Stuttgart) and Protistology (Omsk). For his scientific and organizational achievements, he was repeatedly awarded with state distinctions and decorations (including the Officer's Cross of the Order of Polonia Restituta - 1998).
Andrzej Grębecki urodził się 3 stycznia 1934 r. w Tomaszowie Mazowieckim, jako syn Tadeusza i Zofii $z$ domu Mizerskiej. Oboje rodzice byli nauczycielami. Szkołę średnią ukończył w 1948 r. w Tomaszowie Mazowieckim, majacc 14 lat - zdał egzamin maturalny za zezwoleniem i przed Komisją Ministerstwa Edukacji Narodowej. Pracę zawodowa rozpoczał w 1950 r., jako asystent w Zakładzie Biologii Eksperymentalnej Uniwersytetu Łódzkiego. Był w tym czasie uczniem i współpracownikiem jednego z najwybitniejszych polskich biologów, prof. Jana Dembowskiego. Studia wyższe odbył w latach 1948-1952 na Wydziale Biologii i Nauk o Ziemi (do 1951 r. Wydział Matematyczno-Przyrodniczy) Uniwersytetu Łódzkiego. W 1954 r. przeniósł się wraz ze swym mentorem do Warszawy, do reaktywowanego po wojnie Instytutu Biologii Doświadczalnej im. Marcelego Nenckiego PAN, w którym w latach 1952-1956 odbywał studia doktoranckie. Cała dalsza kariera naukowa Andrzeja Grębeckiego zwiazana była $z$ tym Instytutem, gdzie w 1957 otrzymał stopień kandydata nauk przyrodniczych na podstawie rozprawy doktorskiej pt. „Zjawiska regulacji w hodowlach Paramecium caudatum (oddziaływania na środowisko oraz adaptacji)". W latach 1956-1961 pracowal dodatkowo w niepełnym wymiarze godzin jako adiunkt na Wydziale Biologii i Nauk o Ziemi Uniwersytetu Warszawskiego. W 1964 r. Rada Naukowa Instytutu Nenckiego PAN nadała mu stopień naukowy docenta na podstawie rozprawy „Badania nad elektrofizjologia ruchu i wchłaniania pierwotniaków". Tytuł profesora nadzwyczajnego uzyskał w 1981 r., a profesora zwyczajnego w 1989 r.

W latach 1967-1973 Andrzej Grębecki został oddelegowany do pracy w Sekretariacie UNESCO w Paryżu, gdzie zajmował się programami nauczania biologii. Kilka lat spędził w wielu krajach afrykańskich, szkolacc tamtejsze kadry reformujace programy i metody nauczania biologii w szkołach średnich.

Po powrocie do kraju w 1973 r. Andrzej Grębecki stworzył Pracownię Morfodynamiki Prostych Systemów Ruchowych w Zakładzie Biologii Komórki, która kierował do 2002 r. Najbliższymi współpracownikami Andrzeja Grębeckiego byli: Lucyna Grębecka, Małgorzata Cieślawska, Wanda Kłopocka, Joanna 
Kołodziejczyk, Mariola Moczoń i Paweł Pomorski. W ich pamięci pozostał wspaniałym mentorem. Człowiekiem pełnym empatii, życzliwości i zrozumienia dla trosk drugiego człowieka. Te cechy nie zawsze towarzysza relacjom Szef wychowanek W przypadku profesora Grębeckiego wszyscy wychowankowie właśnie w ten sposób charakteryzuja ich wzajemne relacje. Paweł Pomorski napisał: „Profesor Grębecki pokazał mi, że zarzadzanie ludźmi to prowadzenie a nie zaganianie. Dawanie wolności i pokazywanie perspektywy".

Profesor Grębecki aktywnie uczestniczył w życiu Instytutu pełniąc funkcję zastępcy dyrektora d/s naukowych (1975-1981) i kierownika studium doktoranckiego (19751979). Przez dwie kadencje (1984-1989) był przewodniczaccym Rady Naukowej. Tak prof. Nałęcz opisuje aktywność profesora Grębeckiego: „Obecność Profesora Grębeckiego w Instytucie była ważna i widoczna, a jego aktywny udział, w różnych latach, w dyrekcji, w Radzie Naukowej i w gronie kierowników pracowni odegrał znaczaca rolę w obniżaniu napięć, podejmowaniu konstruktywnych dyskusji i wybieraniu rozwiąań chroniących dobro nauki i naukowców w Instytucie Nenckiego".

W roku akademickim 1989/90 pracował na Freie Universität w Berlinie Zachodnim prowadzac badania jako „visiting profesor”.

W latach 1992-2001 profesor Grębecki był członkiem Rady Programowej Polskiej Sieci Biologii Komórkowej i Molekularnej UNESCO/PAN, a w latach 1993-1997 członkiem International Commission of Protozoology.

Ogłosił drukiem 160 prac indywidualnych lub współautorskich. W tej liczbie 75 dotyczyło badań eksperymentalnych z zakresu protozoologii.

Dowodem mieddzynarodowego uznania dorobku prof. Grębeckiego było Jego członkostwo w komitetach redakcyjnych międzynarodowych czasopism naukowych: Acta Protozoologica (Warszawa), European Journal of Protistology (Stuttgart) i Protistology (Omsk). Był także członkiem honorowym francuskich i niemieckich towarzystw protozoologicznych.

Poza praca naukowa Andrzej Grębecki zajmował się popularyzacja nauki, zwłaszcza w dziedzinie biologii ogólnej i teorii ewolucji. W młodości był prelegentem, a następnie konsultantem Zarządu Głównego Towarzystwa Wiedzy Powszechnej. W latach 60. prowadził wykłady we Wszechnicy Telewizyjnej. Wydał kilka skryptów i książek popularno-naukowych a przede wszystkim wielokrotnie wznawiany podręcznik Ogólne zasady biologii (GREBBECKI 1966) (6 wydań 1966-1986).
Za swoje osiagnięcia naukowe i organizacyjne był wielokrotnie nagradzany wyróżnieniami i odznaczeniami państwowymi: 1979, Nagroda Sekretarza Naukowego Polskiej Akademii Nauk; 1985, Nagroda Wydziału Nauk Biologicznych Polskiej Akademii Nauk; 1990, Nagroda Prezesa Polskiej Akademii Nauk; 1979, Złoty Krzyż Zasługi; 1998, Krzyż Oficerski Orderu Odrodzenia Polski.

„Ten Wielki Skromny Człowiek odegrał znaczaca role w nauce, w edukacji, w organizacji nauki i w dyplomacji naukowej zarówno w Instytucie Nenckiego, jak i znacznie szerzej" tak prof. Nałęcz podsumował działalność profesora Andrzeja Grębeckiego.

\section{DZIAŁALNOŚĆ NAUKOWA}

W centrum zainteresowań prof. Grębeckiego była protozoologia doświadczalna i biologia komórki, ze szczególnym uwzględnieniem fizjologii ruchu komórek i ich reagowania na bodźce. W działalności naukowej Andrzeja Grębeckiego można wyróżnić 4 etapy. W pierwszym - do uzyskania doktoratu, wspólnie $z$ Leszkiem Kuźnickim badali reakcje orzęska Paramecium caudatum wobec różnych zwiazków nieorganicznych i organicznych w zależności od zagęszczenia populacji. Autorzy wykazali, że tzw. reakcja obronna skupiania $P$. caudatum ma charakter bierny i polega przede wszystkim na większej adsorpcji czynników trujących (GRĘBECKI i KuźNICKI 1954).

W drugim okresie (1957-67) zainteresowania Andrzeja Grębeckiego skupiły się na reakcjach aparatu rzęskowego u Pramecium oraz jego koordynacji podczas ruchu $i$ fagocytozy. Stwierdził on istnienie zależności między zmianami potencjału elektrokinetycznego powierzchni Paramecium a procesami endocytozy i reakcjami na bodźce aparatu rzęskowego u tego pierwotniaka.

Postęp w poznaniu zjawisk chemotaksji i galwanotaksji Paramecium, jaki dokonał się w latach 60. i 70., był następstwem wprowadzenia nowych technik eksperymentalnych. Makrofotograficzna rejestracja ruchu pierwotniaków, pierwotnie opracowana przez M. L. FERGUSSONA (1957), znalazła szerokie zastosowanie, po modyfikacjach wprowadzonych przez Stanisława Dryla (DRYL 1958), do analizy obu taksji: chemotaksji (Ryc. 1) i galwanotaksji (Ryc. 2) (DRYL i GREBECKI 1966).

Trwająca od kilku do kilkudziesięciu sekund ekspozycja pływajacych orzęsków w ciemnym polu pozwoliła zapisywać ich ruchy na błonach fotograficznych. Na tej podstawie można było dokonywać pomiarów i prowadzić analizy porównawcze i ilościowe. Pierwszą połowę lat 60. Andrzej Grębecki 
poświęcił badaniom galwanotaksji i określeniu potencjału powierzchniowego Paramecium caudatum. Wyniki tych doświadczeń przedstawił $\mathrm{w}$ cyklu prac napisanych po francusku (GREBECKI 1962, 1963a, b, c, d).

Andrzej Grębecki wykazał, że większość zjawisk zwiąanych $z$ reakcjami pantofelków na prąd stały daje się wyjaśnić na podstawie udoskonalonej wersji teorii JAHNA (1961). Dotyczy to również galwanotaksji katodowej u pierwotniaków podczas rewersji rzęskowej. Hiperpolaryzacja błony od strony anody powoduje wzmożona pracę rzęsek, w wyniku której pantofelek płynie ku katodzie. Natomiast depolaryzacja błony komórkowej indukowana jonami potasu wywołuje rewersje rzęskowa od strony katody.

Andrzej Grębecki jest autorem pierwszych $\mathrm{w}$ literaturze prac o roli wapnia $\mathrm{w}$ regulacji ruchu rzęskowego (Grębecki 1964, 1965). Potwierdził on doświadczalnie teoretyczne przeliczenia JAHNA (1962), który w oparciu o wyniki KAMADY i KINOSITY (1940) wykazał, że czas trwania rewersji rzęskowej u Paramecium w obecności jonów wapnia pozostaje stały jeśli $\left.\left[\mathrm{K}^{+}\right] / \mathrm{Ca}^{2+}\right]=$ const. Andrzej Grębecki wykazał, że przy stałym stosunku $\left[\mathrm{K}^{+}\right.$ ]$/\left[\mathrm{Ca}^{2+}\right]$ w środowisku, Paramecium caudatum zachowuje taka samą szybkość ruchu $\mathrm{i}$ te same reakcje rzęskowe niezależnie od bezwzględnych stężeń obu jonów (GREBECKI 1964). Przedstawiona równowaga jest równoznaczna $z$ równowagą Gibbsa-Donnana dla adsorpcji jonów jedno- i dwuwartościowych. $\mathrm{Na}$ tej podstawie Jahn wysuną hipotezę, że rewersja rzęskowa powinna pojawiać się zawsze, kiedy jony wapnia w wyniku konkurencji $z$ innymi jonami sa wypierane $z$ zewnętrznej warstwy błony Paramecium.

Analizując stosowalność równowagi Gibbsa-Donnana dla reakcji ruchowych Paramecium Andrzej GREBECKI (1965) stwierdzil, że $\mathrm{w}$ miarę stopniowej chelatacji bådź przez wytracanie jonów wapnia $\mathrm{w}$ środowisku $\mathrm{u}$ Paramecium pojawiaja się różne reakcje rzęskowe. Grębecki nadał im następujące nazwy, które stosuje się do dzisiaj: FLS (forward left-spiraling movements), FRS (forward right-spiraling movement), CCR (continous ciliary reversal), PCR (periodic ciliary reversal), PaCR (partial ciliary reversal) (Ryc. 3).

Po powrocie z Paryża (1973), w trzecim etapie aktywności naukowej, Andrzej Grębecki skupił się na badaniach mechanizmu ruchu śluzowca Physarum polycephalum i Amoeba proteus.

Trzy rozprawy doktorskie (Małgorzata Cieślawska, 1978; Mariola Moczoń, 1979; Joanna Kołodziejczyk, 1983) oraz cykl publikacji poświęcone były problematyce ruchu śluzowca. Głównie skupiono się na analizie cykli skurczowo-rozkurczowych (CIEŚLAW-
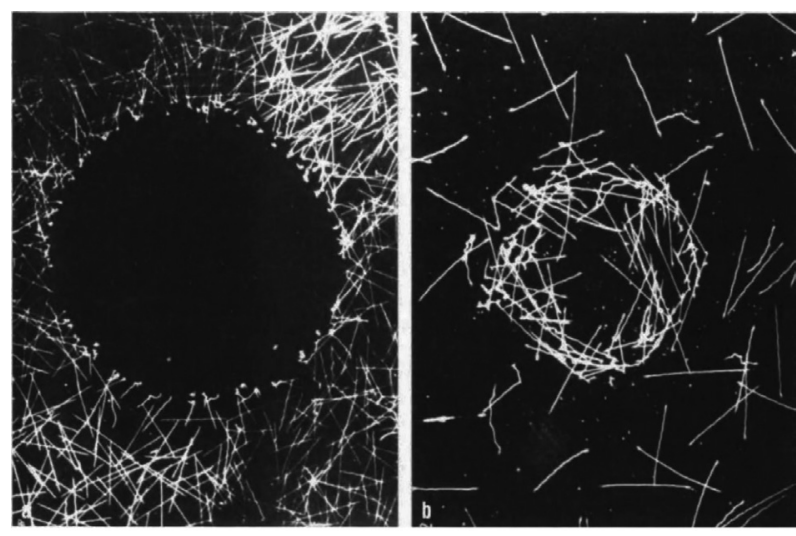

Ryc. 1. Fotomakrograficzna rejestracja chemotasji Paramecium caudatum w stosunku do różnego $\mathrm{pH}$ środowiska.

a) Chemotaksja ujemna wobec środowiska zasadowego. b) Chemotaksja dodatnia w stosunku do środowiska lekko kwaśnego (DRYL i GRĘBECKI 1966).
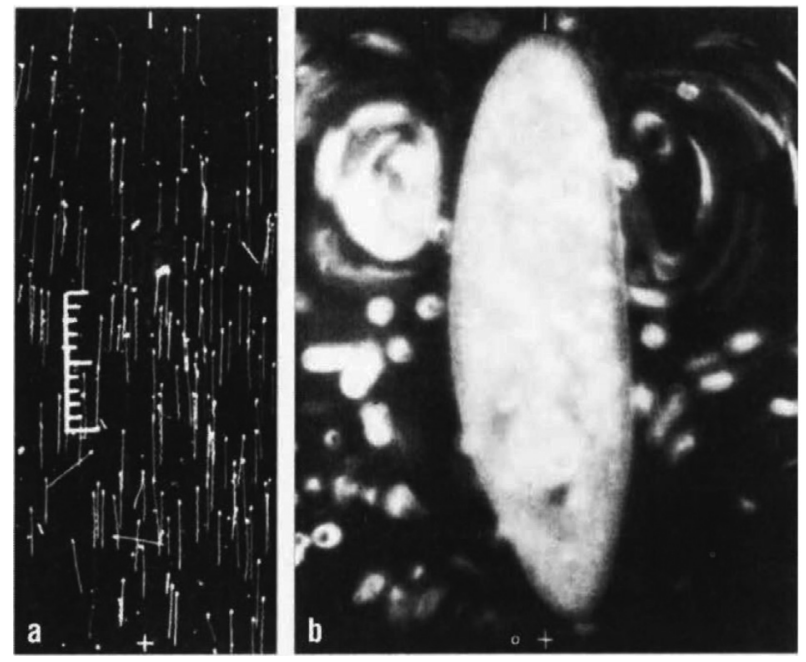

Ryc. 2. Rejestracja reakcji galwanotaktycznej Paramecium caudatum $\mathrm{w}$ ciemnym polu.

a) Ruch populacji orzęsków ku katodzie zarejestrowany technika fotomakrograficzna. Skala $=1 \mathrm{~cm}$. b) Fotomikrograficzna rejestracja wirów powstałych $\mathrm{w}$ następstwie rewersji rzęsek w przedniej części pierwotniaka zwróconej w stronę katody (DRYL i GRĘBECKI 1966).

SKA i GREBECKI 1978a, b), dynamice procesów ruchowych plazmodium na jego froncie i w zakończeniu żyły śluzowca (CIEŚLAWSKA 1980, KoŁODZIEJCZYK i GRĘBECKI 1980) oraz zależnościami między skurczem a oscylacjami pradu cytoplazmatycznego w żyłach (KOŁODZIEJCZYK i GREBECKI 1982, GREBECKI i KOŁODZIEJCZYK 1983), jak również miejscem generacji siły skurczu i jego podbłonowym podłożem aktomiozynowym (KOŁODZIEJCZYK i GREBBECKI 1983，1989; GRĘBECKI i CIEŚlAWSKA 1984). 
Jednak zapoczątkowane w latach 60. badania dotyczace ruchu amebowego zdominowały problematykę opisujaca mechanizm ruchu śluzowców (Ryc. 4).

Do ważnych osiagnięć tego zespołu należy zaliczyć opracowanie nowej klasyfikacji typów morfodynamicznych, występujacych wśród komórek A. proteus. Wyróżniono formy: monotaktyczne o stałej, jednokierunkowej polaryzacji ruchu i braku reakcji na bodźce; ortotaktyczne o polaryzacji jednokierunkowej wywołanej kierunkowym bodźcem; politaktyczne - tylny biegun stały, a na przodzie rozprzestrzenianie się wiodacych nibynóżek oraz formy heterotaktyczne: o polaryzacji wielobiegunowej i przemiennej, jako następstwo bodźców szokowych. Dotychczas w piśmiennictwie dwie pierwsze formy były nazywane monopodialnymi, a dwie ostatnie poliploidalnymi (GREBECKI i GREBECKA 1978).

Ponadto badanie mechanizmu ruchu amebowego $z$ wykorzystaniem metody mikrofotograficznej rejestracji ruchu i analizy filmowej pozwoliło na określenie przestrzennej i czasowej organizacji funkcji ruchowych w poruszajacej się komórce. W oparciu o tę metodę wykonano pomiary zmian rozmiarów poszczególnych funkcjonalnych okolic ciała ameby w trakcie jej ruchu (GREBECKA i GREBECKI 1975). Jak wykazano, ruch amebowy i przepływ cytoplazmy sa wywołane aktyw-
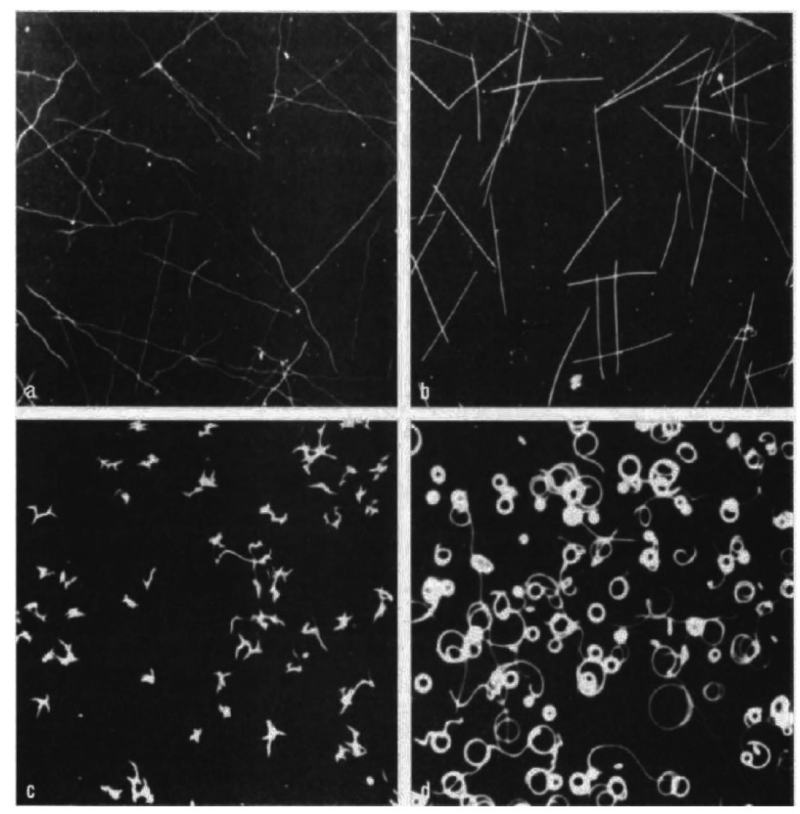

Ryc. 3. Makrofotograficzna rejestracja w ciemnym polu czterech typów ruchu Paramecium caudatum.

a) Ruch do przodu ze spiralizacja lewoskrętna (FLS) normalny, b) Ciagła rewersja rzęskowa (CCR) - pływanie tyłem do przodu. c) Periodyczna rewersja rzęskowa (PCR). d) Częściowa rewersja rzęskowa (PaCR) (DRYL i GREBECKI 1966). nościa skurczowa całej warstwy peryferyjnej komórki (GRĘBECKI 1981, 1982a), przeciwnie niż twierdził Robert Allen (Allen i ALLEN 1978). Ponadto wykazano, że u ameby szczególną rolę sterująca pełni część frontalna wysuwanego pseudopodium wskutek rozrywania kontaktu między błona a cytoszkieletem. Podsumowaniem tego etapu osiagnięć szkoły Grębeckiego w zakresie ruchu amebowego był jego referat podczas VI Międzynarodowego Kongresu Protozoologicznego w Warszawie (1981) pt. „Supramolecular aspects of ameboid movement", w którym sformułował teorię ogólnego skurczu kortykalnego, która weszła do podręczników protozoologii (GRĘBCKI 1982b).

W czwartym etapie swej działalności Andrzej Grębecki wraz $z$ Zespołem rozwijał teorię ogólnego skurczu kortykalnego, wyjaśniając organizację ruchu nie tylko dużych ameb lecz i innych komórek poruszajacych się ruchem amebowym. Szczególne znaczenie miało poznanie współzależności między ruchami peryferyjnego cytoszkieletu ameb a ruchami błony komórkowej (GREBECKI 1984 a, b). Wykazano, że u komórek zawieszonych w środowisku podbłonowa sieć aktynowa wykazuje ciagły ruch wsteczny, a podczas migracji przesuwa się koncentrycznie ku przyczepom komórki do podłoża. Profile prędkości wstecznego przesuwu pod błona wskazuja na równomierna aktywność skurczowa całego korteksu. Podobny charakter ma skurcz warstwy kortykalnej ameby, któ-

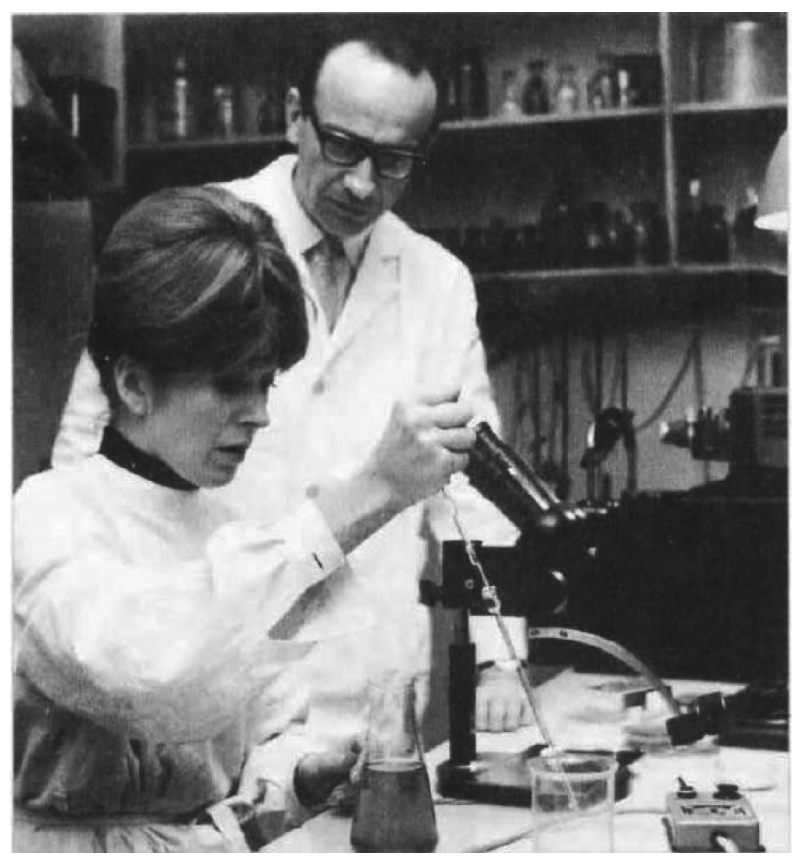

Ryc. 4. Lucyna Czarska (Grębecka) i Andrzej Grębecki, lata 60., początek doświadczeń na amebach. 
ra odzyskała kontakt $z$ podłożem i w następstwie podjęła lokomocję. Andrzej Grębecki przy pomocy komputerowej analizy obrazu zbadał przebieg cyklicznego odrywania się cytoszkieletu od błony we frontach nibynóżek w toku lokomocji i podczas pinocytozy (GREBBECKI 1990, 1991). Badania tego etapu działalności naukowej podsumował $\mathrm{w}$ obszernym artykule monograficznym pt. "Membrane and cytoskeleton flow in motile cells with emphasis on the contribution of free-living amoebae" w International Review of Cytology (GRĘBECKI 1994). Wyjaśnienie zjawisk adhezji miało istotne znaczenie dla poznania mechanizmu ruchu amebowego. Nowe dane w tej sprawie przyniosła publikacja z 1995 (KŁOPOCKA i współaut. 1995). Wyjaśnione i otwarte problemy dotyczace mechanizmów adhezji naświetlił Andrzej Grębecki w pracy, która ukazała się w 1997 (GREBBECKI 1997).

Kontynuując badania nad adhezja komórek ameba prof. Grębecki i współpracownicy skupili się nad udziałem cytoszkieletu aktynowego podczas tworzenia punktów przyczepu ameby do podłoża. Wykazali oni, że kompleksy F-aktyny obecne w strukturach adhezyjnych $A$. proteus (minipodia) zanikaja, gdy komórka traci kontakt $z$ podłożem, a pojawiaja się, gdy ponownie zaczyna do niego przylegać (GREBECKA i współaut. 1997, GREBBECKI i współaut. 2001a, b).

Przedstawiony powyżej materiał stanowi jedynie wybór najważniejszych problemów naukowych, które badał i próbował wyjaśnić prof. Andrzej Grębecki, autor ponad 160. publikacji naukowych, często zostawiając je otwartymi do dyskusji lub dalszego zgłębiania.

Andrzej Grębecki we wspomnieniach osób znajacych i współpracujacych $z$ Nim był człowiekiem bezgranicznie oddanym nauce, nieprzeciętnie zdolnym. Niezwykłym obserwatorem, badaczem, który $z$ nieprawdopodobna łatwościa formułował myśli, był prekursorem ważnych nurtów w protozoologii światowej, a przy tym człowiekiem bardzo skromnym, otwartym na problemy osób z którymi współpracował.

\section{REFERENCJE}

Allen R. D., Allen S. S., 1978. Cytoplasmic streaming in ameboid movement. Ann. Rev. Biophys. Bioeng. 7, 469-495.

CIEŚLAWSKA M., 1980. Dynamics of the ending veins in plasmodia of Physarum polycephalum. Acta Protozool. 19, 143-152.

Cieślawska M., GREBBeCKI A., 1978a. Contractionexpansion cycles in plasmodia of Physarum polycephalum observed in polarized light. Acta Protozool. 17, 525-531.

CIEŚlAWSKA M., GREBECKI A., 1978b. Contractionexpansion rhythms simultaneously observed in two sites of Physarum polycephalum. Acta Protozool. 17, 533-541.

DRYL S., 1958. Photographic registration of movement of protozoa. Bull. Acad. Pol. Sci., Ser. Biol. 6, 429-430.

DRYL S., GREBECKI A., 1966. Progress in the study of excitation and response of ciliates. Protoplasma 62, 255-284.

FERGUSSON M. L., 1957. Photografic technique for quantitative studies of Paramecium and other motile cells. Physiol. Zool. 30, 208-215.

GREBECKA L., GREBECKI A., 1975. Morphometric study of moving Amoeba proteus. Acta Protozool. 14, 337-361.

GREBECKA L. POMORSKI P., GREBECKI A, ŁOPATOWSKA A., 1997. Adhesion-dependent F-actin in Amoeba proteus as a common feature of amoebae and the metazoan motile cells. Cell Biol. Int. 21, 565-573.

GREBECKI A., KUŹNICKI L., 1954. Działanie toksyczne soli nieorganicznych na Paramecium caudatum. Kosmos 3, 618-619.

GREBBECKI A., 1962. Phénomènes électrocinetiques dans le galvanotropisme de aramecium caudatum. Bull. Biol. Fran. Bel. 96, 723-754.

GREBECKI A., 1963a. Point isoélectrique superficiel et quelques réactions locomotorices chez Paramecium caudatum. Protoplasma 56, 80-88.

GREBECKI A., 1963b. Electrobiologie d'ingestion des colorants par le cytostome de Paramecium caudatum. Protoplasma 56, 89-98.

GREBECKI A., 1963c. Galvanotaxie transversale et obique chez les ciliés. Acta Protozool. 1, 9198.

GREBECKI A., 1963d. Rebroussement ciliaire et galvanotaxie chez Paramecium caudatum. Acta Protozool. 1, 99-112.

GREBECKI A., 1964. Role des ions $K^{+}$et Ca: + dans 1'excitabilite de la cellule protozaire. I. Equilibrement des ions antagonistes. Acta Protozool. 2, 69-79.

GREBECKI A., 1965. Role of Ca2+ ions in the excitability of protozoan cell. Decalcification, recalcification, and the ciliary reversal in Paramecium caudatum. Acta Protozool. 3, 275-289.

GREBECKI A., 1966. Ogólne zasady biologii. Państwowe Zakłady Wydawnictw Szkolnych.

GREBECKI A., 1981. Effects of localized photic stimulation on amoeboid movement and their theroretical implications. Eur. J. Cell Biol. 24, 163-175.

GREBECKI A., 1982a. Etudes expérimentales sur la localisation des fonction motrices chez amibes. Ann. Biol. 21, 275-306.

GREBECKI A., 1982b. Supramolecular aspects of amoeboid movement. Progress in Protozoology, Proc. VI Int. Congr. Protozool. 117-130.

GREBECKI A., 1984a. Relative motion in Amoeba proteus in respect to the adhesion sites. I. Behaviour of monotactic forms and the mechanism of fountain phenomenon. Protopasma 123, 116-134.

GREBECKI A., 1984b. Relative motion in Amoeba proteus in respect to the adhesion sites. II. Ectoplasmic and surface movements in polytactic and heterotactic amoebae. Protoplasma 127, 31-45.

GREBECKI A., 1990. Dynamics of the contractile system in the pseudopodial tips of normally locomoting amoebae, demonstrated in vivo by video-enhancement. Protoplasma 154, 98-111.

GREBECKI A., 1991. Participation of the contractile system in endocytosis demonstrated in vivo by video-enhancement in heat-pretreated amoebae. Protoplasma 160, 144-158. 
GREBECKI A., 1994. Membrane and cytoskieleton flow in motile cells with emphasis on the contribution of free living amoebae. Inter. Rev. Cytol. 148, 37-80.

GREBECKI A., 1997. Cell-substratum interaction of Amoeba proteus: old and new open questions. [W:] Dynamics of cell and tissue motion. ALT W., DEuTsch A., DunN G. (red.). Springer, $117-122$

GREBBECKI A., KuŹNICKI L. 1954. Działanie toksyczne soli nieorganicznych na Paramecium caudatum. Kosmos 3, 618-619.

GreBECKI A., GREBECKA L., 1978. Morphodynamic types of Amoeba proteus a terminological proposal. Protistologica 14, 349-358.

GrEBECKI A., KolODZIEJCZYK J., 1983. Contraction and streaming relations recorded simultaneously at two points along the plasmodia veins and frontal channels of Physarum polycephalum. Acta Protozool. 22, 1-18.

GręBECKI A., CiEŚlAWsKA M., 1984. Motive force generation site in plasmodium of Physarum polycephalum, a dissection study. Acta Protozool. 23, 123-134.

GREBECKI A., GREBECKA L., WASIK A., 2001 a. Minipodia, the adhesive structures active in locomotion and endocytosis of amoebae. Acta Protozool. 40, 235-247.

GręBECKI A., GREBECKA L., WASIK A. 2001b. Minipodia and rosette contacts are adhesive organelles present in free-living amoebae. Cell Biol. Intern. Rep. 25, 1279-1283.

JAHN T. L., 1961. The mechanism of ciliary movement. I. Ciliary reversal and activation by elec- tric current; the Ludloff phenomenon in terms of core and colume conductors. J. Protozool. 8, 369-380.

JAHN T. L., 1962. The mechanism of ciliary movement. II. Ion antagonism and ciliary reversal. J. Cellular Comp. Physiol. 60, 217-228.

KAMADA T., KinOSITA H., 1940. Calcium-potasium factor in ciliary reversal of Paramecium. Proc. Jap. Acad. 16, 125-130.

KoŁODZIEJCZYK J., GREBECKI A., 1980. Dynamics of the frontal margin of plasmodia of Physarum polycephalum. Acta Protozool. 19, 153163.

KolODZIEJCZYK J., GREBECKI A., 1982. Further studies on the relation between contraction and streaming oscillations in the plasmodial veins of Physarum polycephalum. Acta Protozool. 21,37-53.

KOŁODZIEJCZYK J., GREBECKI A., 1983. Effects of white-red illumination changes on the coordination of some motor functions in plasmodia of Physarum polycephalum. Acta Protozool. 22, 19-31.

KotoDZIEJCZYK J., GREBECKI A., 1989. Dynamics of the submembrane contractile system

in caffeine-derived protoplasmic droplets of Physarum polycephalum. Acta Protozool. 28, 1-10.

KŁOPOCKA W., KOŁODZIEJCZYK J., ŁOPATOWSKA A., GREBECKA L., GREBECKI A., 1995. Resumption of locomotion by Amoeba proteus readhering to different substrata. Protoplasma 189, 180186. 